\title{
Development and Subsequent Neural Tube Effects on the Excitability of Cultured Xenopus Myocytes ${ }^{1}$
}

\author{
P. DECINO ${ }^{2}$ AND Y. KIDOKORO 3 \\ The Salk Institute, Molecular Neurobiology Laboratory, San Diego, California 92138
}

\begin{abstract}
We examined both (1) the development of electrical excitability in cultured Xenopus muscle over a period of 7 days, and (2) the effects of neural tube on the muscle action potential. During muscle development, delayed and anomalous rectification were present in most cases within $24 \mathrm{hr}$. The action potential was dependent on $\mathrm{Na}$ at all times examined, and the rate of rise of the action potential ( $\dot{\mathbf{V}}_{\max }$ ) increased substantially (seven-fold) from the first 2 days to 6 to 7 days in vitro, reflecting an increase in $\mathrm{Na}$ current density. In order to determine the mechanism for the increase in $\dot{\mathbf{V}}_{\max }$, we examined single-channel $\mathrm{Na}$ currents using the gigaseal technique. Single-channel conductance $(\gamma)$ did not increase substantially when measured using the patch clamp technique: $\gamma=24 \mathrm{pS}$ at 1 to 2 days, and $\gamma=28 \mathrm{pS}$ at 4 to 6 days. The channel open time at $14^{\circ} \mathrm{C}$ was $0.6 \mathrm{msec}$ for $1-$ to 2-day-old cells and $0.5 \mathrm{msec}$ in 4- to 6-day-old cells at a step potential $\mathbf{4 0} \mathrm{mV}$ from rest. The time constant for current decay as well as the time-to-peak current also did not change over time. Thus, channel kinetics appear unchanged. The maximum inward current from summed records was statistically greater for older cells, and the frequency of patches displaying single-channel events increased from 75 to $98 \%$. Thus, we conclude that during development in vitro, $\mathrm{Na}$ current density increases as a result of an increase in channel density without detectable alterations in single-channel properties.
\end{abstract}

Neural tube addition led to a further increase in $\dot{\mathbf{V}}_{\max }$ (twofold), even in muscle cells with no apparent nerve contact. Single channel analysis of cells in coculture revealed $\gamma$ to be $28 \mathrm{pS}$ in three cells displaying a single amplitude peak for individual $\mathrm{Na}$ currents. In the majority of cases $(9 / 12)$, however, there appeared to be two classes of $\mathrm{Na}$ channels present which were difficult to separate. The larger conductance channel likely corresponds to the $28 \mathrm{pS}$ class. The

Received June 18, 1984; Revised October 3, 1984;

Accepted November 9, 1984

${ }^{1}$ We thank Drs. D. Armstrong, S. Sine, J. H. Steinbach, and A. Traynor for their helpful comments on the manuscript, Dr. W. Chen for writing some of the computer programs, M. Stevens for technical assistance, and B. Harkins and N. Goodknight for preparing the manuscript. P. D. was supported by Muscular Dystrophy Association and National Research Service Award fellowships. The research was supported by National Institutes of Health Grant NS11918 and the Muscular Dystrophy Association.

${ }^{2}$ To whom correspondence should be addressed, at her present address: La Jolla Cancer Research Foundation, 10901 N. Torrey Pines Rd., La Jolla, CA 92037.

${ }^{3}$ Current address: Jerry I ewis Neluromuscular Research Ctr., UCl.A School of Medicine, Los Angeles, CA 90024. smaller channels, when present, did not contribute substantially to the population of events comprising the amplitude histogram. Other single-channel kinetic parameters also did not change. We, therefore, conclude that neural tube addition does not effect activation or inactivation kinetics but likely causes a further increase in channel density and possibly the induction of a second type of $\mathrm{Na}$ channel.

Embryonic nerve and muscle cells undergo a variety of changes in their membrane properties which allow them to function as mature, excitable cells. Both the distribution and functional characteristics of ionic channels can be modified during development. Some of these changes continue to occur in isolated cells developing in culture, but others depend upon extrinsic factors such as innervation. Voltage and chemically galed ion channels have been studied in a number of systems to determine how the properties of these channels are modified during development and subsequent innervation. One such channel, the acetylcholine receptor (AChR) on cultured Xenopus muscle, has been studied extensively in this laboratory (see Kidokoro et al., 1982). Both the open time and the conductance of these channels change during development and are altered upon addition of neural tube cells. The first part of this paper examines whether developmental changes occur in the channels involved in action potential (AP) generation in cultured Xenopus muscle. The second section investigates the effect of adding dissociated cells from the embryonic neural tube on the voltage-sensitive $\mathrm{Na}$ channel.

The AP of vertebrate excitable cells usually displays substantial changes as the cells mature. Young cells often respond passively when depolarized. In time, an AP develops and its maximum rate of rise $\left(\dot{V}_{\max }\right)$ increases. In neurons (Baccaglini and Spitzer, 1977; Willard, 1980) and striated muscle (Kano et al., 1972; Kano, 1975; Kidokoro, 1975; Spector and Prives, 1977), there is a shift from the initial Ca-dependent spike to one that is $\mathrm{Na}$-dependent (with an occasional residual $\mathrm{Ca}$ component). Delayed rectification usually is present from the time when a regenerative response is first observed. The above observations on changes in ionic dependence of the action potential suggest that increased inward current during spike generation can be accounted for by an addition of functional $\mathrm{Na}$ channels which have faster activation kinetics than Ca channels. In many cases, the $\mathrm{Na}$ channels appear to eventually replace $\mathrm{Ca}$ channels. In studies looking specifically at the development of $\mathrm{Na}$ channels in cultured chick (Frelin et al., 1981; Baumgold et al., 1983a, b; Strichartz et al., 1983) and rat (Sherman and Catterall, 1982,1983 ) muscle, the density of these channels has been shown to increase over time. For chick muscle, the increase was accompanied by a concommitant increase in $\dot{V}_{\max }$ and batrachotoxinstimulated ${ }^{22} \mathrm{Na}$ flux, suggesting the addition of functional channels. Whether the functional characteristics changed in single $\mathrm{Na}$ channels has not been examined.

Tetrodotoxin (TTX) sensitivity of $\mathrm{Na}$ channels has been examined extensively during development and upon denervation. In rat muscle, 
early in development (Harris and Marshall, 1973) and after denervation (Redfern and Thesleff, 1971; Harris and Thesleff, 1971), at least a portion of the Na channels become resistant to TTX. In the chicken and frog, however, denervation does not result in a TTX-resistant AP (Harris et al., 1973; Nasledov and Thesleff, 1974). Little has been done to examine whether denervation in vivo or the addition of nerve in vitro causes alterations in Na channel properties. Voltage-clamp analysis of denervated rat muscle (Pappone, 1980) showed that the only detectable change in TTX-sensitive macroscopic current was a shift to more negative potentials in the voltage dependence of activation and inactivation kinetics. In cultured chick muscle exposed to nerve extract, electrophysiological measurements suggested that $\mathrm{Na}$ channel density increased, although alterations in individual channel properties were not examined (Kano et al., 1979).

We have used intracellular and patch recording techniques to determine the developmental changes of voltage-gated channels in cultured Xenopus muscle and the subsequent effect of the addition of dissociated neural tube cells on the $\mathrm{Na}$ action potential in these muscle cells. Na channels carry inward current from the earliest time studied. The amount of current increases with time in culture, reflecting a change in $\mathrm{Na}$ channel density rather than alterations in either channel kinetics or unitary conductance. Neural tube addition induces a detectable increase in $\dot{V}_{\max }$, but the analysis of individual $\mathrm{Na}$ channel currents is complicated. Most muscle cells exhibit at least two types of $\mathrm{Na}$ channels which were not easily separated. The addition of neural tube to muscle cultures seems to increase $\mathrm{Na}$ current by increasing the density of $\mathrm{Na}$ channels, possibly through the induction of a second channel type. The single channel properties of the major class of $\mathrm{Na}$ channels, however, was unaffected by neural tube addition.

\section{Materials and Methods}

\section{Cultures}

Myotomes from Xenopus laevis embryos were dissociated and cultured as described by Kidokoro et al. (1980) with some modifications. The dorsal portions of stage 18 to 27 embryos (Nieuwkoop and Faber, 1967) were isolated with dissecting needles in $60 \%$ ( $/ \mathrm{v}$ ) HEPES-buffered Dulbeccomodified Eagle's medium (with $5 \%$ horse serum (GIBCO), $50 \mu \mathrm{g} / \mathrm{ml}$ gentamycin (Shering) and $50 \mathrm{unit} / \mathrm{ml}$ mycostatin (GlBCO)). Myotomes were separated from the surrounding tissue in $0.1 \%$ collagenase (Worthington) in 67 $\mathrm{mM} \mathrm{NaCl}, 1.5 \mathrm{mM} \mathrm{KCl}, 0.5 \mathrm{mM} \mathrm{CaCl}_{2}$, and $8 \mathrm{mM} \mathrm{HEPES-NaOH}, \mathrm{pH} 7.4$. Individual muscle cells were obtained by incubating myotomes in $2 \mathrm{mM}$ EDTA, $67 \mathrm{~mm} \mathrm{NaCl}, 1.6 \mathrm{~mm} \mathrm{KCl}$, and $8 \mathrm{~mm}$ HEPES-NaOH (pH 7.4). Cells were then plated in $60 \%$ HEPES-buffered Dulbecco-modified Eagle's medium with either $0,0.5$, or $5 \%$ horse serum. After one day, the concentration of serum was reduced to $0.5 \%$ from $5 \%$. For nerve-muscle cocultures, dissociated neural tube cells from stage 18 to 20 embryos were added to 1 - to 3 day old muscle cultures. Experiments were done 2 to 4 days after adding the neural tube cells when the muscle cultures were 4 to 6 days old. Cultures were kept at room temperature $\left(21-24^{\circ} \mathrm{C}\right)$

\section{Solutions}

The recording solulion for all experiments was $120 \mathrm{~mm} \mathrm{NaCl}, 1.6 \mathrm{~mm} \mathrm{KCl}$, $10 \mathrm{mM} \mathrm{CaCl}_{2}, 8 \mathrm{~mm}$ HEPES-NaOH $(\mathrm{pH}$ 7.4). Tetrodotoxin, tetraethylammonium, and 4 aminopyridine were obtained from Sigma.

\section{Electrophysiology}

A single microelectrode (50 to 100 megohms) filled with $3 \mathrm{~m}$ potassium acetate and $10 \mathrm{~mm}$ potassium chloride was used to pass current and measure membrane potential via a bridge circuit in a Biodyne Electronics AM-1 amplifier. The voltage response was differentiated electronically. Voltage, $\mathrm{dv} / \mathrm{dt}$, and current records were then stored on a Racal Store 4DS tape recorder (10 kHz band width) for later analysis. Small hyperpolarizing pulses were used to determine the input resistance $\left(R_{i n}\right)$ and the membrane time constant $\left(\tau_{m}\right)$ before depolarizing the cell to elicit an AP. In $40 \%$ of the cases, the membrane potential was held at approximately $-90 \mathrm{mV}$ if they initially were below $-80 \mathrm{mV}$. The current pulse experiments were done at room temperature $\left(21-24^{\circ} \mathrm{C}\right)$.

Single-channel current recordings were made with Sylgard (Dow-Corning) coated electrodes (flint glass, 3 to 10 megohms) according to the method outlined by Hamill et al. (1981). Electrodes contained $120 \mathrm{mM} \mathrm{NaCl}, 1.6 \mathrm{~mm}$ $\mathrm{KCl}, 0.5 \mathrm{~mm}$ EGTA, and $8 \mathrm{~mm}$ HEPES- $\mathrm{NaOH}(\mathrm{pH} 7.4$ ) when recording from cell attached patches. Records were stored on tape directly from a Meyer and Renz MPCS-V3 patch clamp amplifier which contained a transient cancellation circuit. The fully compensated, unfiltered patch clamp current had a 10 to $90 \%$ rise time of $45 \mu \mathrm{sec}$.

Throughout the paper, voltage steps are reported as the displacement from the resting potential (for example, a 40-mv step depolarizes the patch membrane by $40 \mathrm{mV}$ ). in some cases, the membrane potential was estimated by rupturing the patch membrane and determining the voltage which produced zero current. Membrane potential was corrected for a liquid junction potential of $1.5 \mathrm{mV}$. In most patch clamp experiments, the cells were cooled to slow down the rates of channel opening and closing. Except where noted, the temperature was $14 \pm 1^{\circ} \mathrm{C}(\mathrm{SD})$.

\section{Data analysis}

Cell size was measured to estimate specific membrane resistance $\left(R_{m}\right)$ and capacitance $\left(C_{m}\right)$. Photomicrographs were printed $(X 1900)$ and the cells' circumferences traced with an HP 9864A digitizer interfaced with an HP 9830A computer. The measured area was doubled to give total surface area.

Passive properties. $R_{m}$ was calculated by multiplying $R_{\text {in }}$ by the surface area. $C_{m}$ could then be calculated from the membrane time constant.

Active propertics. Voltage, current, and dv/dt records were played back and filmed to measure relevant parameters on the HP minicomputer or they were digitized on a MINC 11/23 computer for similar analysis. Threshold was estirnaled Irom AP records as the point which voltage clearly deviated from a completely passive response.

Means are plus or minus standard deviation except as noted. Statistical comparisons were made using the nonparametric Mann-Whitney $U$-test (Siegel, 1956) which can be used on populations the distributions of which are non-normal or unknown.

Single channel records. These records were analyzed by individual channel analysis and/or summing multiple traces to mimic whole cell currents (Sigworth and Neher, 1980). For both methods, the analogue data was digitized at a $25-$ to $50-\mu \mathrm{sec}$ sampling rate on the MINC 11/23.

For summing purposes, 15 to 60 depolarizing pulses were filtered at 3 to $4 \mathrm{kHz}$ ( $-3 \mathrm{~dB}$ frequency; Bcssel response) and added along with an equal number of hyperpolarized pulses to remove leakage currents. The resulting peak current was measured by eye. Since, even at $11-12^{\circ} \mathrm{C}$, the rising phase of the inward current was not well resolved, only the time-to-peak current and the decay rate of the inward current $\left(\tau_{h}\right)$ were routinely measured. $\tau_{h}$ was estimated by fitting the decay current to an exponential by eye. Visual titting gave $\tau_{\mathrm{h}}$ estimates within $8 \%$ of theoretical values for synthetic data with superimposed noise. $\tau_{h}$ was corrected to $14^{\circ} \mathrm{C}$ using a $Q_{10}$ of 2.85 (see Frankenhaeuser and Moore, 1963).

Individual records were filtered at $3 \mathrm{kHz}$ and digitized at $25-$ to $30-\mu \mathrm{sec}$ intervals for analysis of single channel currents. Six to ten hyperpolarizing pulses of equal amplitude were averaged, and the average was added to each record for leakage correction. The base line and open state level were fitted by eye. The open and close transitions were then set visually to coincide with the half-maximal value. Events briefer than $150 \mu \mathrm{scc}$ were excluded from analysis. In cases in which only a few events $(<50)$ were recorded at a given potential, the open times were averaged for comparison between cells of different culture ages. These values overestirnate the true mean open time by an amount equal to the short duration cutoff point (i.e., $150 \mu \mathrm{sec}$; Neher and Steinbach, 1978). The averaged open times and open times determined by fitting histograms with a single exponential $\left(\tau_{0}\right)$ were corrected to a temperature of $14^{\circ} \mathrm{C}$ using a $Q_{10}$ of 2.3 (Frankenhaeuser and Moore, 1963).

\section{Results}

\section{Excitability in muscle cells}

The majority of experiments described here were done on cultures from stage 18 to 20 embryos. Results from stage 18 embryos (preinnervation; Kullberg et al., 1977; Chow and Cohen, 1983) did not appear different from those on older embryos (up to stage 27).

Cultured Xenopus myotomal cells remain healthy for more than 1 week under the culture conditions used here. During the initial 3 to 4 days, they grow to their maximum size, approximately doublng their surface area (Table I). Figure 1 shows examples of a small 1 . day-old muscle cell and a 5-day-old cell. When examining the cells' electrical properties, there was often considerable variability. To 
TABLE I

Properties from sister cultures

\begin{tabular}{|c|c|c|c|c|c|c|c|}
\hline $\begin{array}{l}\text { Days } \\
\text { in } \\
\text { Culture }\end{array}$ & $\begin{array}{c}\text { Surface } \\
\text { Area } \\
\left(\mu \mathrm{m}^{2}\right)^{a}\end{array}$ & $\begin{array}{c}E_{r} \\
(\mathrm{mV})\end{array}$ & $\begin{array}{c}R_{\text {in }} \\
\text { (megohms) }\end{array}$ & $\begin{array}{c}\tau_{m} \\
\text { (msec) }\end{array}$ & $\begin{array}{c}R_{m}{ }^{b} \\
\text { (kilohm-cm }{ }^{2} \text { ) }\end{array}$ & $\begin{array}{c}C_{m}{ }^{c} \\
\left(\mu \mathrm{F} / \mathrm{cm}^{2}\right)\end{array}$ & $\begin{array}{c}V_{\max } \\
(\mathrm{V} / \mathrm{sec})\end{array}$ \\
\hline 1 & $\begin{array}{c}3565 \pm 1416 \\
(61)^{d}\end{array}$ & $\begin{array}{c}-98 \pm 8 \\
(6)\end{array}$ & $\begin{array}{c}256 \pm 122 \\
(7)\end{array}$ & $\begin{array}{c}18 \pm 5 \\
(7)\end{array}$ & 9.1 & 2.0 & $\begin{array}{c}26 \pm 26 \\
(5)\end{array}$ \\
\hline 6 & $\begin{array}{c}6964 \pm 3011^{\circ} \\
(61)\end{array}$ & $\begin{array}{c}-96 \pm 6 \\
(13)\end{array}$ & $\begin{array}{c}122 \pm 40^{\circ} \\
(14)\end{array}$ & $\begin{array}{c}17 \pm 4 \\
(17)\end{array}$ & 8.5 & 2.0 & $\begin{array}{c}82 \pm 40^{\circ} \\
\text { (13) }\end{array}$ \\
\hline
\end{tabular}

${ }^{a}$ Values for surface area, $E_{r}, R_{\mathrm{in}}, \tau_{m}$, and $\dot{V}_{\max }$ are expressed as mean $\pm \mathrm{SD}$.

${ }^{b} R_{m}=R_{\text {in }} \times$ surface area.

${ }^{c} C_{m}=\tau_{m} / R_{m}$

${ }^{d}$ Numbers in parentheses, number of cells.

- Statistically significant change between days 1 and $6, P=0.001$, Student's $t$ test.
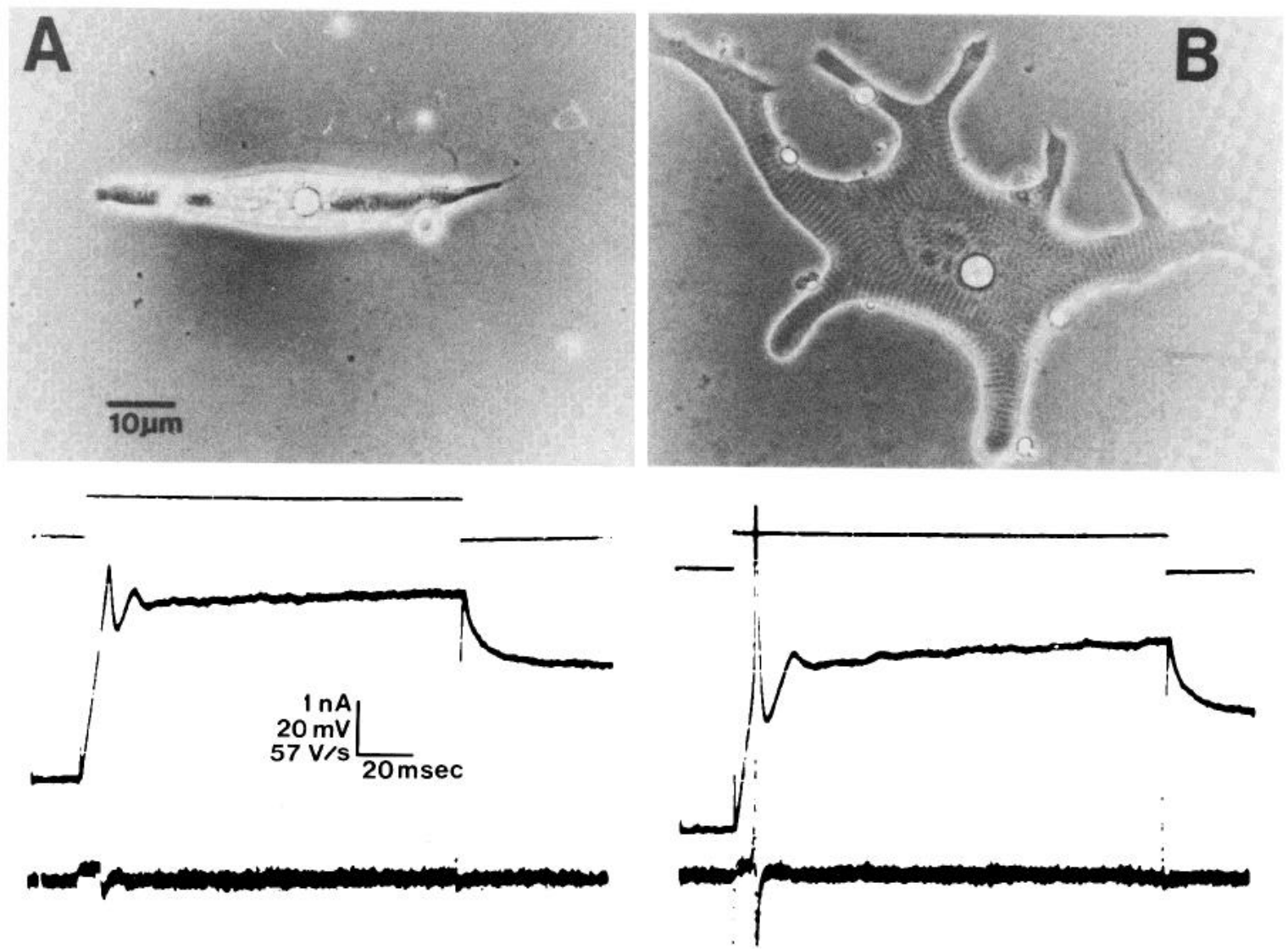

Figure 1. Morphology and action potentials from different aged cells. A shows a typically shaped, but somewhat small, 1-day-old muscle cell and a representative action potential from a different 1-day-old cell. B shows a 5-day-old muscle cell. In each lower panel, the top trace is current, the middle trace is voltage, and the bottom trace is $\mathrm{dV} / \mathrm{dt}$. Zero current also represents the zero potential point. The voltage did not return to the previous resting level after the stimulation ended due to contraction-induced damage.

minimize this variability, cells were compared between sister cultures whenever possible. In addition, although myotomal cells do not fuse in culture, they do become electrically coupled to contacted myotomal cells. Therefore, all intracellular measurements were made on isolated cells.

Passive membrane properties. Table I shows the data on passive electrical properties obtained from one set of sister cultures sampled at 1,3 , and 6 days. The specific membrane resistance $(\sim 10$ kilohms$\left.\mathrm{cm}^{2}\right)$ and capacitance $\left(\sim 2 \mu \mathrm{F} / \mathrm{cm}^{2}\right)$ do not change while the input resistance falls to about half its initial value by day 6 . The reduction in input resistance can be accounted for entirely by the increase in the cells' surface area. The value for $C_{m}$ is higher than that found in nerve and most likely reflects a contribution from transverse tubules as seen in the electron microscope (G. Klier, personal communication). The resting potential is also unchanged, as measured by intracellular methods. This result was later confirmed using the patch electrode (see "Materials and Methods") where 1-day-old muscle cells had a resting potential of $-89 \pm 3 \mathrm{mV}(n=7)$.

Ionic channels involved in the action potential. The shape of the active response to depolarization, at least in older cultures, suggested that the ion channel involved in the upstroke was the voltagedependent $\mathrm{Na}$ channel (Figs. 1 and 2). Substitution of extracellular $\mathrm{Na}$ with Tris completely abolished the spike in 1-day-old and 6-dayold muscle cells. As an additional test, 0.1 to $3 \mu \mathrm{M}$ tetrodotoxin (TTX) was added to the bathing solution. TTX eliminated the fast spike in young (1-day; Fig. $2 A_{2}$ ) and older (5-day; Fig. $2 B_{2}$ ) cells; 

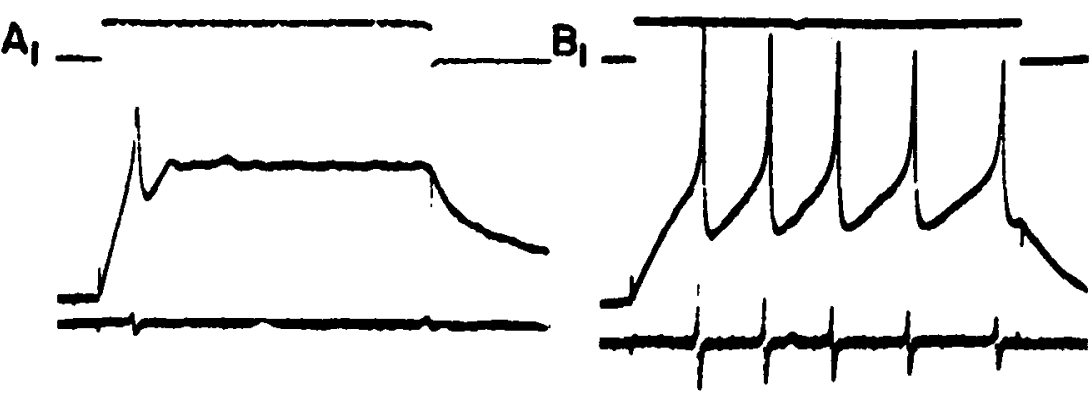

Figure 2. lonic dependence. $A$ is from 1-day muscle cells; $B$ from 5-day-old cells. $A_{1}$ and $B_{1}$ are responses from cells in normal recording solution. In $A_{2}, B_{2}$, and $B_{3} \Pi X(3$ $\mu \mathrm{M})$ and tetraethyiammonium $(10 \mathrm{mM})$ have been added to the bathing solution. $A_{3}$ and $B_{3}$ are examples of the prolonged depolarization following stimulus cessation. Top trace, current; middle trace, voltage, third trace, if present, $\mathrm{dV} / \mathrm{dt}$. Vertical scale bar is $0.4 \mathrm{nA}, 20 \mathrm{mV}$, or $114 \mathrm{~V} / \mathrm{sec}$. Horizontal scale bar is $20 \mathrm{msec}$ in $\mathrm{A}_{1}, \mathrm{~B}_{1}, \mathrm{~A}_{2} ; 50 \mathrm{msec}$ in $B_{2} ; 100 \mathrm{msec}$ in $B_{3}$ and $200 \mathrm{msec}$ in $A_{3}$.

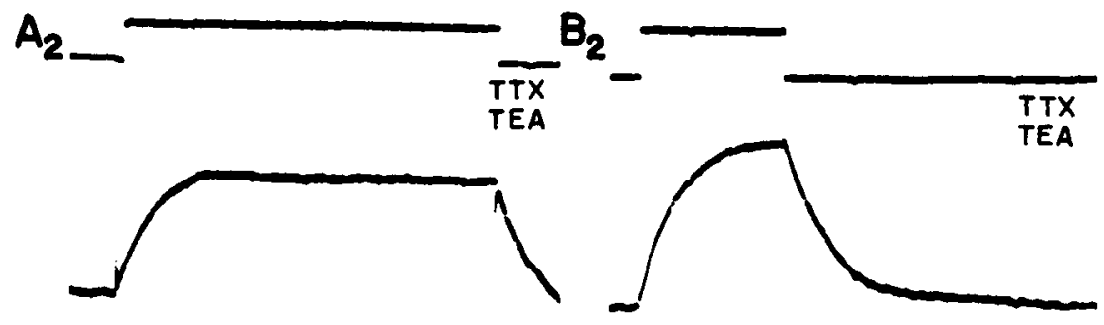

$A_{3}$

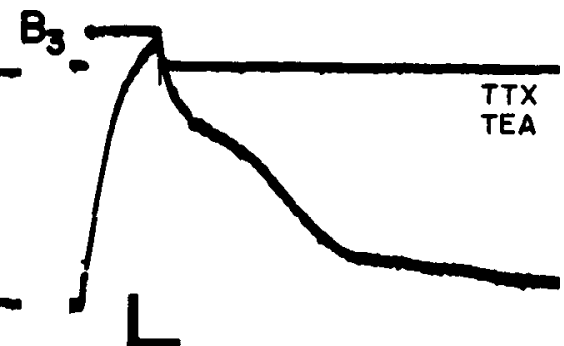

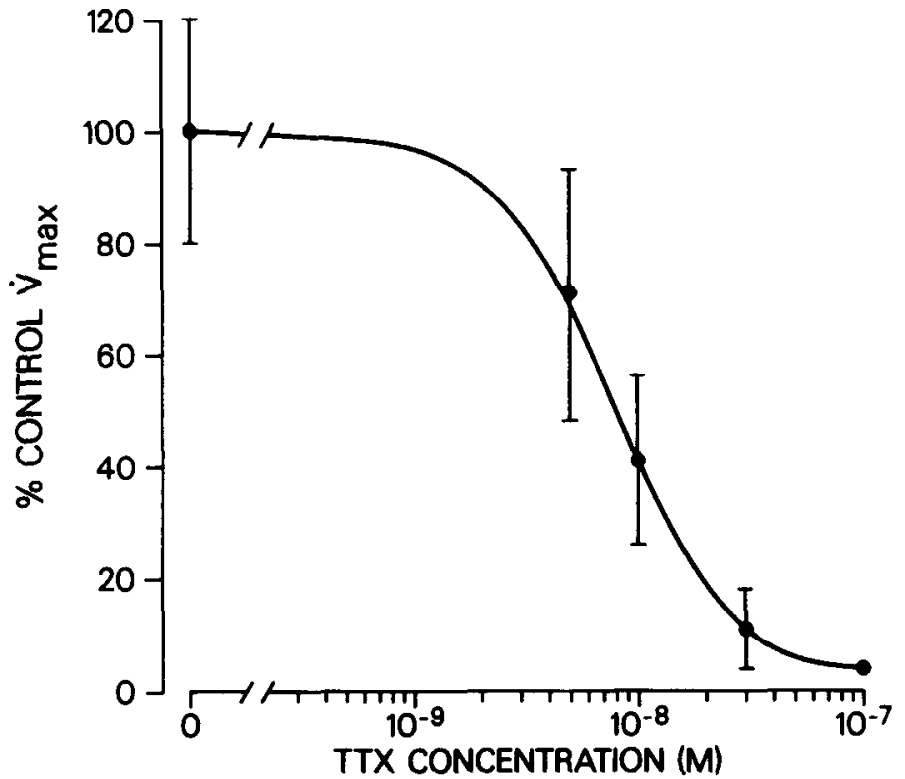

Figure 3. $V_{\max }$ sensitivity to TTX. Each point is the average \pm SE of seven to nine points. Control $\dot{V}_{\max }$ is the response in 0 TTX. The curve is drawn by eye.

TTX did not reveal a second inward current during the stimulus (however, see below).

Since immature or denervated muscle cells are often less sensitive to TTX, the TTX concentration was measured which reduced $\dot{V}_{\max }$ by half $\left(K_{0.5}\right)$. This experiment was only performed on cells of at least 3 days in culture, since $\dot{V}_{\max }$ was sufficiently small in younger cells to make this measurement inaccurate. Figure 3 shows the dose response curve from cells 3 days after culturing. $K_{0.5}$ does not shift

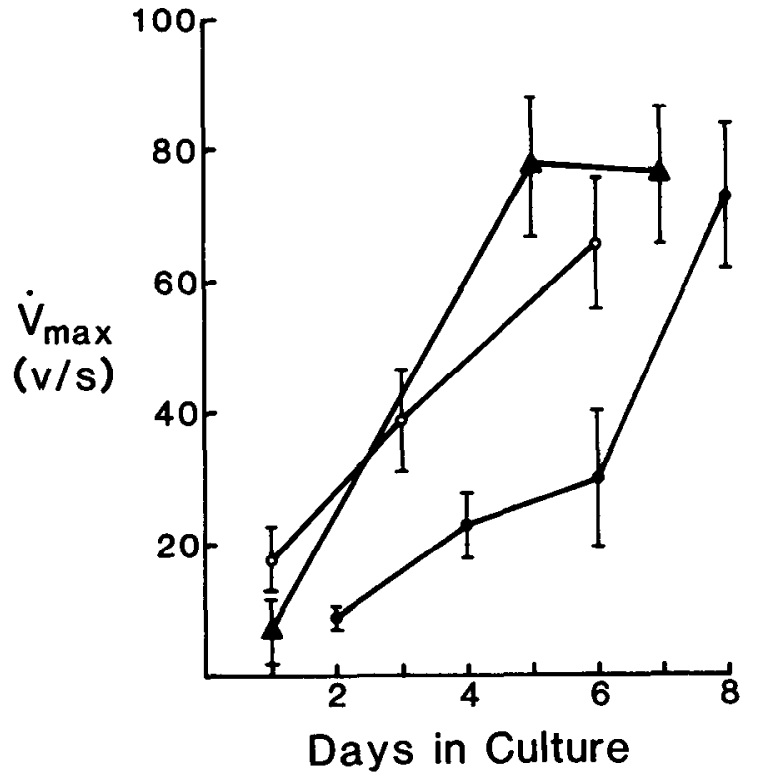

Figure 4. Examples of $\dot{V}_{\max }$ versus time in culture. Each point represents the mean $\pm \operatorname{SE}(n=8$ to 25 ). Means from sister cultures at different times are connected to one another. O, stage 19 embryos; $\boldsymbol{\Lambda}$, stage 22 embryos; - stage 19 to 20 embryos.

to smaller values in older cells over the time period examined; the mean $K_{0.5}$ for 6 experiments from 3 to 7 days in vitro was $9 \mathrm{~mm}$. These results indicate that there is not a significant TTX-insensitive channel population present after 3 days.

Both delayed and anomalous rectification were observed from steady state I-V plots in most cells as early as day 1 (data not shown). No effort was made to characterize these potassium channels. However, the delayed rectifier may obscure an inward $\mathrm{Ca}$ 
A

B

$$
\downarrow
$$

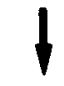

$30 \mathrm{~min} n \mathrm{nw}$

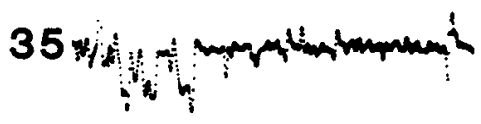

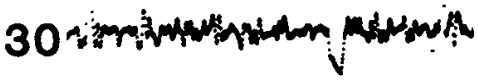

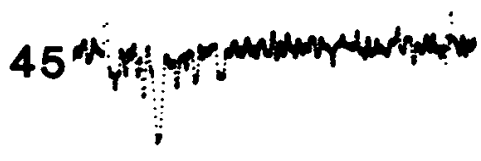

Figure 5. Single channel records from 1-day-old $(A)$ and 4day-old $(B)$ muscle cells. Arrows indicate on and off time of stimulus pulse. Voltage steps from rest are indicated to the left of each record. Sample interval $=30 \mu \mathrm{sec} ; f_{c}=2 \mathrm{kHz} . T=10^{\circ} \mathrm{C}$ in $A, 13^{\circ} \mathrm{C}$ in $B$.
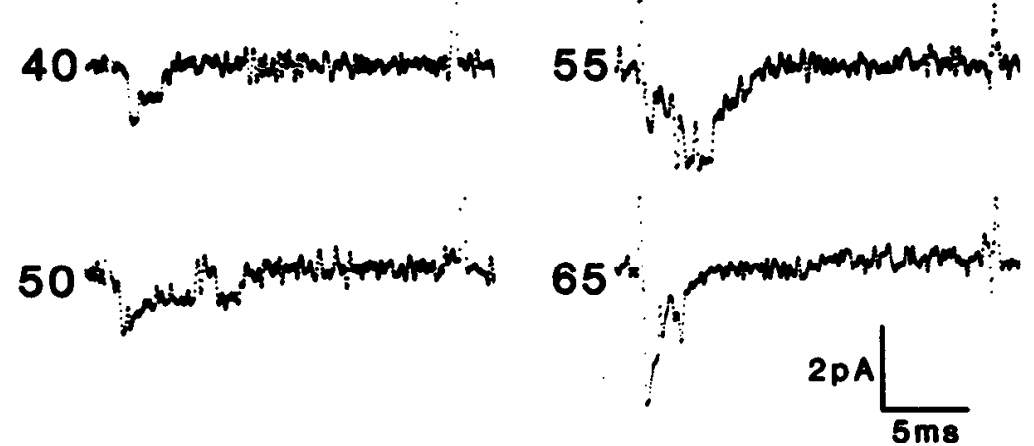

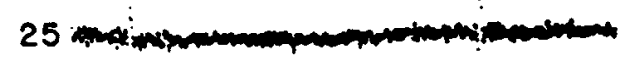

35

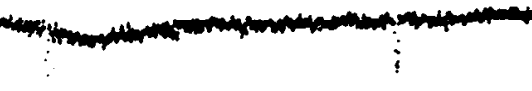

40

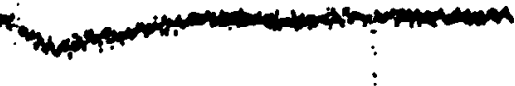

45

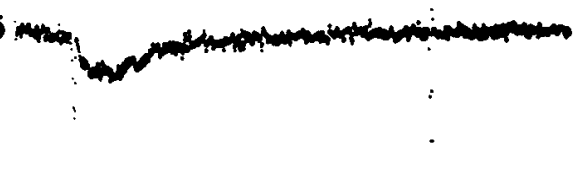

55

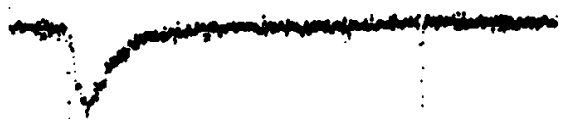

65

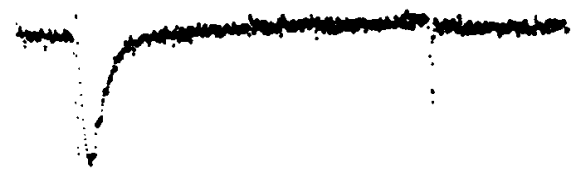

75
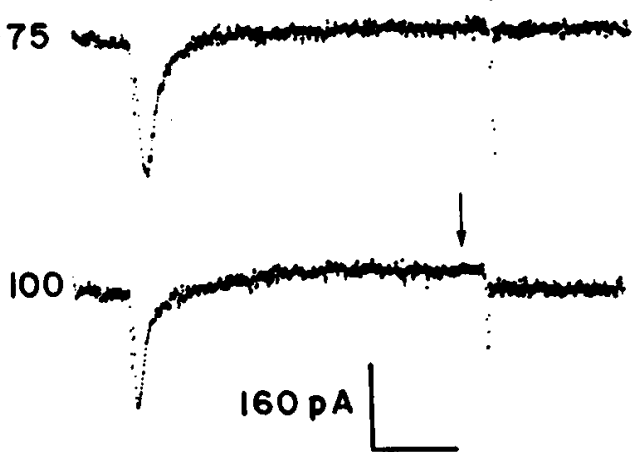

$4.8 \mathrm{~ms}$
Figure 6. Summed single channel records from a 4-day-old muscle cell. Potential step from $E_{\text {, is given }}$ to the left of each trace. Sample interval $=30 \mu \mathrm{sec} ; f_{c}=4 \mathrm{kHz} ; T=$ $13^{\circ} \mathrm{C} .50$ depolarizing records were added at each voltage step. The arrow indicates outward current. current which has been observed in other developing systems. Indeed, on occasion, a slow repolarization was seen after the stimulus was turned off. This slow repolarization occurred in young cells without any channel blockers present (Fig. $2 A_{3}$ ) and in mature cells in the presence of TTX and tetraethylammonium (Fig. $2 B_{3}$ ). To unmask a possible $\mathrm{Ca}$ current, especially during the stimulation period, $10 \mathrm{~mm}$ tetraethylammonium and $5 \mathrm{~mm}$ 4-aminopyridine were added to the bath along with TTX. However, from steady state $\mathrm{H} V$ plots, these two compounds did not appear to completely block the $\mathrm{K}$ conductance when applied to the bath. Bath applied $\mathrm{Ba}(0.25$ to 

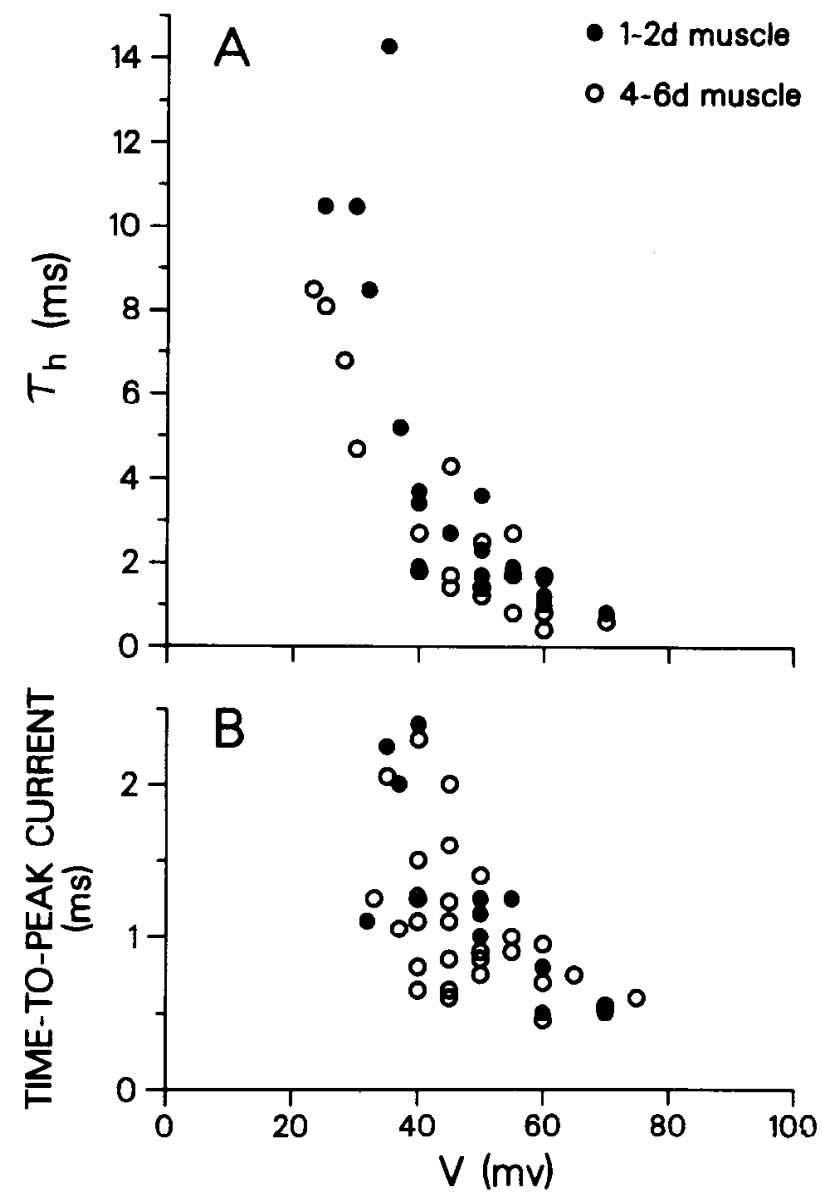

Figure 7. $\tau_{h}$ and time-to-peak current for two age groups. $A$ shows $\tau_{h}$, and $B$ shows time-to-peak current plotted against voltage: 1 , young cells; $O$, old cells. These parameters are not corrected for temperature. $T=14 \pm$ $1^{\circ} \mathrm{C}$.

$1 \mathrm{~mm}$ ) was also ineffective in unmasking Ca channels, since the membrane potential was very unstable with this cation present. Since the slow repolarization off response was infrequent and the ability to uncover another possible inward current was unsuccessful, the conductance underlying the off-response was not further studied. Therefore, we cannot rule out the possibility that a $\mathrm{Ca}$ component was involved during the steady-state phase of the depolarizing pulse or in the off response. The change in $\mathrm{Na}$ current with time was next studied by measuring $\dot{\mathrm{V}}_{\max }$.

Rate of rise of the action potential. A bathing solution of high $\mathrm{Na}$ $(120 \mathrm{~mm})$ and $\mathrm{Ca}(10 \mathrm{~mm})$ was used in these experiments to facilitate detecting $\mathrm{Na}$ and $\mathrm{Ca}$ components in the $\mathrm{AP}$ and to stabilize the membrane potential. In the high $\mathrm{Na} / \mathrm{Ca}$ solution, action potentials often appeared within $24 \mathrm{hr}$ after culturing of the myocytes. $\dot{V}_{\max }$ was measured to study the change in the AP with time. Figure 4 shows the change in $\dot{V}_{\max }$ in three different sets of cultures. Often by day $5, \dot{V}_{\max }$ had reached its maximum value of 46 to $141 \mathrm{~V} / \mathrm{sec}$, although the cultures were never examined beyond 8 days. In nine sets of cultures made from stage 18 to 20 embryos the average increase in $\dot{V}_{\max }$ was 7.5 -fold from the first observation (day 1 to 2) to the last observation ( $\geq 5$ days). Cultures from older embryos (up to stage 27) showed the same trend. In addition to having a faster rate of rise, older cells in vitro occasionally displayed multiple APs during a prolonged depolarization (see Figs. 1 and $2 B_{1}$ ).

The augmentation in $\dot{V}_{\max }$ reflects an increase in $\mathrm{Na}$ current density, since the specific membrane resistance and capacitance do not change. The possible explanation for this finding is a shift in $\mathrm{Na}$ channel activation to more hyperpolarized potentials. This shift would result in more $\mathrm{Na}$ channels becoming activated at a given
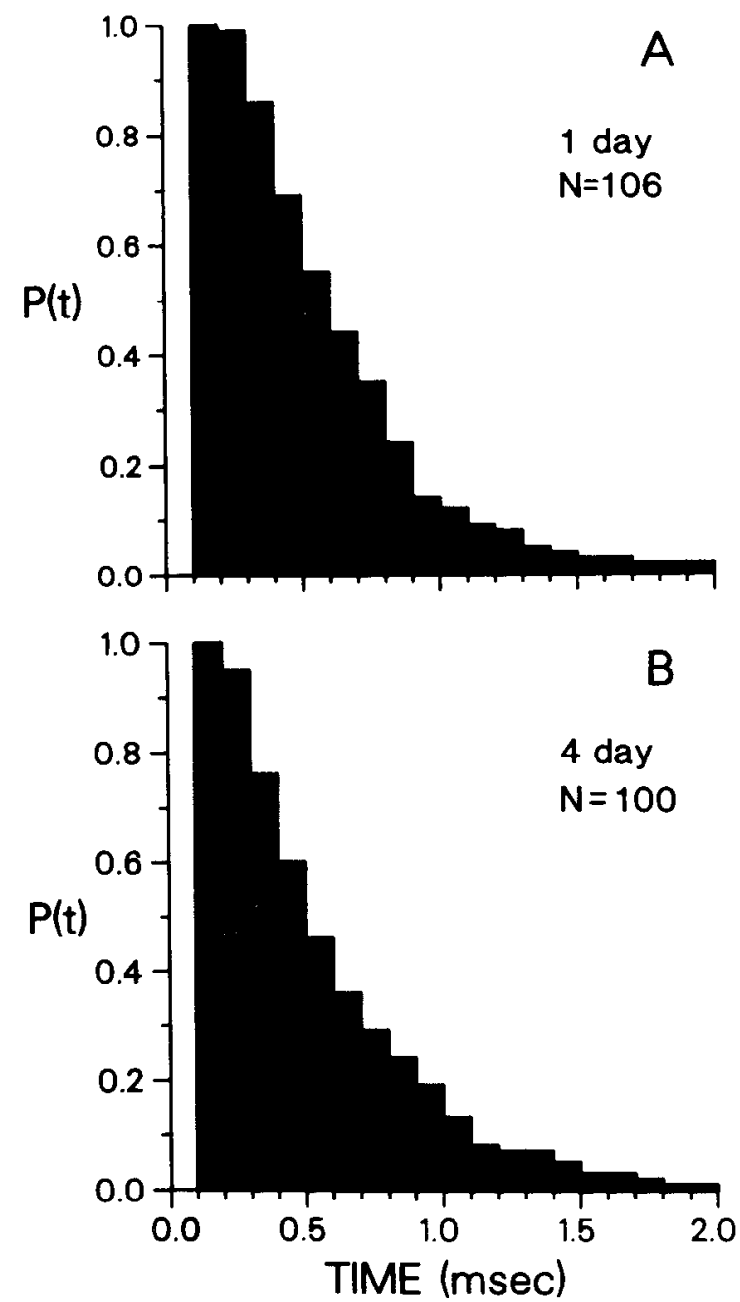

Figure 8. Open time histograms. $P(t)$ is the probability that the opening is $t$ msec or longer. $A$, from 1-day muscle cell; $T=15^{\circ} \mathrm{C}, \tau_{0}=0.38 \mathrm{msec}$; $B$, 4-day muscle cell, $T=13^{\circ} \mathrm{C}, \tau_{0}=0.44 \mathrm{msec}$.

voltage, thus increasing $\dot{V}_{\max }$, while reducing the number of channels being inactivated during the time required for the membrane to discharge. To test for a shift in $\mathrm{Na}$ channel inactivation, threshold was estimated. Threshold was similar for 1-day-old cells $(-36 \pm 8$ $\mathrm{mV} ; n=15)$ and 6- to 7 -day-old cells $(-38 \pm 9 \mathrm{mV} ; n=22)$. This result and evidence from single channel analysis presented below suggest that no voltage shift in activation kinetics occurs as the cells mature.

Single channel currents. At least three possibilities could account for the increased $\mathrm{Na}$ current during the AP: (1) increased singlechannel conductance in mature cells; (2) alterations in activation and/or inactivation kinetics; and (3) an increase in $\mathrm{Na}$ channel density. The first two possibilities can be examined electrophysiologically. Indirect evidence supports the last possibility.

For these experiments, cultures were separated into two age groups: young cultures were 1 to 2 days old, and old cultures were at least 4 days old. Single-channel recordings were obtained from cell-attached patches to closely mimic the conditions in which $\dot{V}_{\max }$ was measured. Although the membrane potential is unknown in this instance, we showed earlier that there were no changes in the cells' membrane potential during development in vitro. Therefore, comparisons of single-channel properties between different aged cells is valid.

Initially, single-channel recordings were made using the same solution in the electrode as in the bath with $10 \mathrm{~mm} \mathrm{Ca}$. However, individual $\mathrm{Na}$ currents were difficult to resolve in high $\mathrm{Ca}$. Therefore, the $\mathrm{Ca}$ was removed and EGTA $(0.5 \mathrm{~mm})$ was added. This solution 


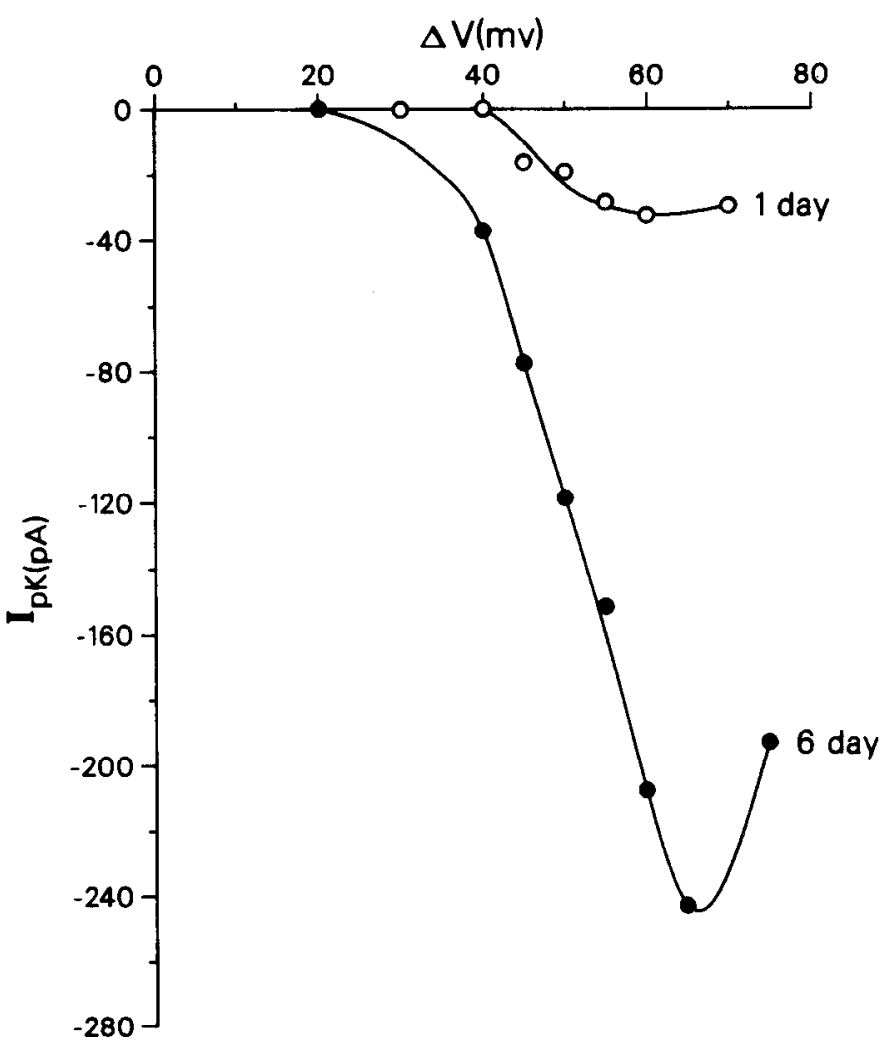

Figure 9. I-V plot of voltage step versus peak inward current obtained from summed records from sister cultures. 50 depolarizing traces at each potential were added. $T=9^{\circ} \mathrm{C}$ for 1 -day cell, $12^{\circ} \mathrm{C}$ for 6 -day cell.

resulted in a two-fold increase in unitary current amplitude. This augmentation in $\mathrm{Na}$ current amplitude is likely due to either the decreased surface potential screening (Ohmori and Yoshii, 1977) or the removal of the blocking effect by $\mathrm{Ca}$ (Yamamoto et al., 1983) when $\mathrm{Ca}$ is absent from the external surface of the membrane.

To test that the single-channel currents we recorded were actually arising from $\mathrm{Na}$ channels, either $3 \mu \mathrm{M}$ TTX was added or $\mathrm{Na}$ was removed from the electrode solution (with Tris substitution). In nine patches where this was done, none displayed any single-channel activity. In contrast, $85 \%$ (79/93) of the patches from all aged cells ( 1 to 6 days) with the normal electrode solution had channel openings during a depolarizing voltage step of $50 \mathrm{mV}$ or more.

In six of 20 patches examined closely, there were individual outward current events. In these cases, the presumptive $\mathrm{K}$ currents appeared at potentials steps of $50 \mathrm{mV}$ or more from the resting potential. The driving force for $K$ current is not very large in the range of potentials used here, so many of the outward $K$ currents may go undetected. Because they appeared later during the stimulus than $\mathrm{Na}$ channels, there was not a problem with contamination, except occasionally when measuring $\tau_{h}$ (see below).

Figure 5 shows examples of single-channel $\mathrm{Na}$ currents from a 1 day and 4-day culture, each at a number of different step potential levels. It is apparcnt that the unitary current does not differ substantially between these different aged cultures. The unitary current for the 1-day culture (Fig. 5A) was 1.7 pA and, for the 4-day culture (Fig. $5 B$ ), it was $1.9 \mathrm{pA}$ at $40 \mathrm{mV}$. The voltage level at which single channel events first appeared was variable, being as low as $10 \mathrm{mV}$ from resting level but more usually starting at $30 \mathrm{mV}$. This threshold is approximately $-65 \mathrm{mV}$ in absolute terms, which is considerably more hyperpolarized than threshold measured intracellularly $(-36$ to $-38 \mathrm{mV})$. The shift, however, is expected since, in the patch recording experiments, the stabilizing effect of $\mathrm{Ca}$ on the membrane has been removed.

After $\mathrm{Na}$ currents were first detected, the potential was stepped in increments of 2 to $10 \mathrm{mV}$. Because step size varied, the numbers of records at any given potential is small, but comparisons at multiple voltage levels show consistent trends. Comparisons of the unitary currents from seven young ( 1.7 to $2.7 \mathrm{pA})$ and seven old cells ( 1.8 to $2.6 \mathrm{pA}$ ) at $40 \mathrm{mV}$ revealed no differences by the nonparametric Mann-Whitney $U$-test (Siegel, 1956). The single-channel events were composed of a single class of amplitudes although, in a few patches, there appeared to be a channel of smaller conductance. However, its frequency of occurrence was very low, and it was not included in the single channel analysis. Due to low numbers of resolvable single-channel events at each multiple potential steps, unitary conductance $(\gamma)$ estimates were obtained from the slopes of I-V plots in only a few cases. From five young cells, $\gamma$ was $24 \pm 9 \mathrm{pS}$; in older cells $(n=7), \gamma$ was $28 \pm 6 \mathrm{pS}\left(T=14 \pm 2^{\circ} \mathrm{C}\right)$. This difference is not significant (Mann-Whitney U-test: $p>0.1$ ).

Since an increase in unitary conductance did not seem to be the mechanism by which these cells increase their Na current, an alteration in channel kinetics might be responsible. Slowing the inactivation process or augmenting activation could result in increased $\mathrm{Na}$ current. Channel kinetics were examined by first measuring the decay time constant $\left(\tau_{h}\right)$ of current traces obtained by summing a number of sequential single channel records (Sigworth and Neher, 1980). An example of such a treatment is shown in Figure 6, which is from a 4-day-old cultured myocyte. In most cases, the decay of current could be well fit by a single exponential. Where there seemed to be more than one component, the initial, faster portion was fit to a single exponential, and this time constant was used for $\tau_{h}$. Any contribution by a second, slower component may arise in part from outward $K$ current (see Fig. 6; $V=65,75$, and $100 \mathrm{mV}$ ). Figure $7 A$ plots $\tau_{h}$ against potential for the two age groups. As can be seen in this figure, the older cells do not have a longer time course of current decay which would prolong $\mathrm{Na}$ flux through its voltage-gated channel.

From Figure 6, one sees that the activation step is very fast. By cooling the preparation, we had hoped to better resolve singlechannel openings; however, in all but two instances (see for example, Figure 6), the rising phase of the summed response could not be detected clearly, even when cooled to $9^{\circ} \mathrm{C}$. This was due in part to incomplete cancellation of the stimulus artifact. It was not possible, therefore, to measure a time constant for the activation process. As an indirect estimate of activation, the time-to-peak current was measured and plotted for each potential (Fig. 7B). As with $\tau_{h}$, there is no indication that older cells have altered their activation kinetics.

As another means of looking at the kinetic properties of the $\mathrm{Na}$ channel, the open time of individual channels can be measured. Averages were used to compare the two age groups, although these values overestimated the true opentimes (see "Materials and Methods"). Comparisons of average opentimes at a given potential level showed no differences. For example, at $40 \mathrm{mV}$, the average open time was $0.60 \mathrm{msec}(n=9)$ and $0.53 \mathrm{msec}(n=9)$ for young and old cells, respectively. Under optimal conditions, open time histograms were constructed when there were more than 50 events in order to obtain approximate mean open time $\left(\tau_{0}\right)$ values. In general, these histograms were well fit by eye to a single exponential in spite of the relatively few numbers of events. The two examples shown in Figure 8 ( $A, 1$-day; $B, 4$-day) taken at $35 \mathrm{mV}$ are very similar. At $40 \mathrm{mV}, \tau_{0}$ was $0.60 \pm 0.12(n=3)$ for young cells and $0.45 \pm 0.47$ $(n=6)$ in old cells. This also supports the conclusion that there is no obvious alteration in the $\mathrm{Na}$ channel opentime during in vitro development.

The increase in $\dot{V}_{\max }$ seen with time in culture reflects an increase in inward current during the AP upstroke. To better substantiate this finding that inward current density increases, the peak current $\left(I_{\rho k}\right)$ was measured from summed current records. Maximum $I_{p k}$ was determined only in those cells in which the potential steps were great enough to cause $I_{p k}$ to pass through a maximum value. For young cells, the maximum $I_{\text {ok }}$ elicited was in the range of 32 to 162 pA $(n=4)$ for 50 summed records. This does not include two 
Figure 10. Histograms of $\dot{V}_{\max } \dot{V}_{\max }$ was measured in cells from 11 muscle cultures $(A)$ and 13 nerve-muscle cultures in which the cells were classified either as contacted by neurites $(C)$ or not contacted $(B)$.

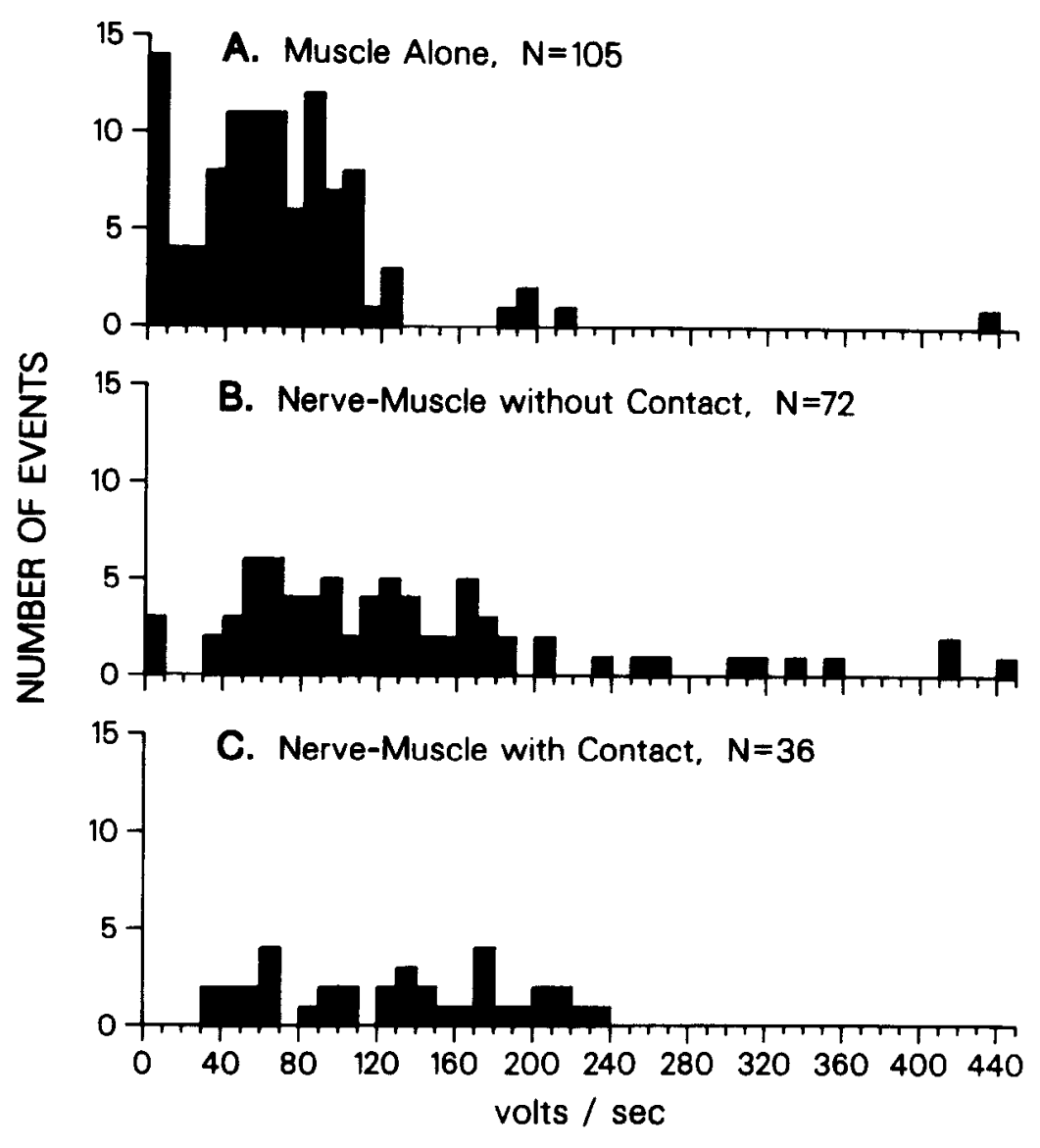

patches which had channels but undetectable summed current $(<5$ pA for 50 summed depolarizing records). In old cells, the maximum current range was 197 to $338 \mathrm{pA}(n=4)$ for the same number of added records. Statistically, this change in $I_{p k}$ represents a significant difference belween young and old cells $(P=0.014$; Mann-Whitney $U$-test). The size of the electrode which probably effects the surface area of the patch of membrane being recorded from was similar for all of these cells. The potential at which this maximum current was reached was approximately $60 \mathrm{mV}$ from rest in both cases. Figure 9 shows a particularly good example in which $l_{p k}$ was compared between two sister cultures at 1 and 6 days in vitro. Here the maximum $I_{D k}$ is 7 times greater at 6 days than at 1 day. It should be noted that the apparent shift in threshold for inward current at 1 day (Figure 9 ) is due to the inability to detect small summed currents. In fact, single channel events were present at 30 and $40 \mathrm{mV}$ in the 1day-old cell. The above results raise the possibility that since unitary conductance and channel kinetics do not change developmentally, then channel density most likely is increasing.

The evidence presented suggests that cultured Xenopus muscle cclls augment their inward current during an AP by increasing $\mathrm{Na}$ channel density. In support of this hypothesis, the percentage of membrane patches containing $\mathrm{Na}$ channels (determined by visually monitoring at least 20 stimuli at depolarizations at $50 \mathrm{mV}$ or more) was $75 \%(39 / 52)$ in young cells and $98 \%(40 / 41)$ in older cells. Even in patches containing $\mathrm{Na}$ channels, $I_{o k}$ for summed records was undetectable in two of 11 young cells, indicating that there were too few channel openings to make a significant contribution. On the other hand, in older cells all 17 of 17 summed records had measurable $I_{\text {ok. }}$.

\section{Effects of neural tube addition on muscle excitability}

Maximum rate of rise of the action potential. Nerve-muscle cocultures were examined 2 days or more after the addition of neural tube cells. The muscle cultures were at least 4 days old, so the $\mathrm{Na-}$ dependent AP was already well developed in these cells. $\dot{V}_{\max }$ was compared between muscle cultures with and without neural tube. In addition, cells in the cocultures were identified as to whether they were nerve-contacted. Figure 10 shows histograms of $\dot{V}_{\max }$ values obtained from cells in muscle cultures (Fig. 10A), nerve-contacted cells (Fig. 10B), and noncontacted cells in cocultures (Fig. 10C). As can be seen, there is wide variability in each group. Much of the dispersion arises from comparing nonsister cultures, but there was considerable variation even between cells within a given culture dish or between different sister culture dishes. $\dot{V}_{\max }$ from cells in coculture, whether neurite-contacted or not, showed a significant increase when compared to $\dot{V}_{\text {max }}$ from muscle cultures $(\rho<0.001)$. The overall increase in $\dot{V}_{\max }$ is 2.3-fold when cells from panels $B$ and $C$ are combined. It thus appears that actual nerve contacl is not a prerequisite for increased $\dot{V}_{\max }$, although the classified "noncontacted" cells in coculture may at some time before recording have been in contact with a neuron. For the remainder of the paper, all cells in nerve-muscie coculture are considered together and as a group are compared to cells in muscle cultures.

The cause for the increase in $\dot{V}_{\max }$ was not due to changes in resting potential or threshold. The average resting potential in $\mathrm{co}$ cultures was the same $(-92 \pm 6 \mathrm{mV} ; n=59)$ as in muscle cultures $(-92 \pm 6 \mathrm{~m} \mathrm{~V} ; n=77)$. Threshold measured in two experiments was comparable between sister muscle and nerve-muscle cultures ( -42 versus $-40 \mathrm{mV}$ and -45 versus $50 \mathrm{mV}$ ). Therefore, the augmented $\dot{V}_{\max }$ suggests that neural tube addition causes muscle cells to increase their $\mathrm{Na}$ current density. Subsequent single-channel experiments on muscle and nerve-muscle cultures were performed to determine the mechanism for the increased $\dot{V}_{\text {max }}$.

Single-channel currents. The previous results suggested the increase in $\dot{V}_{\max }$ seen in cocultures could be accounted for by an increase in $\mathrm{Na}$ channel density without alterations in individual $\mathrm{Na}$ 


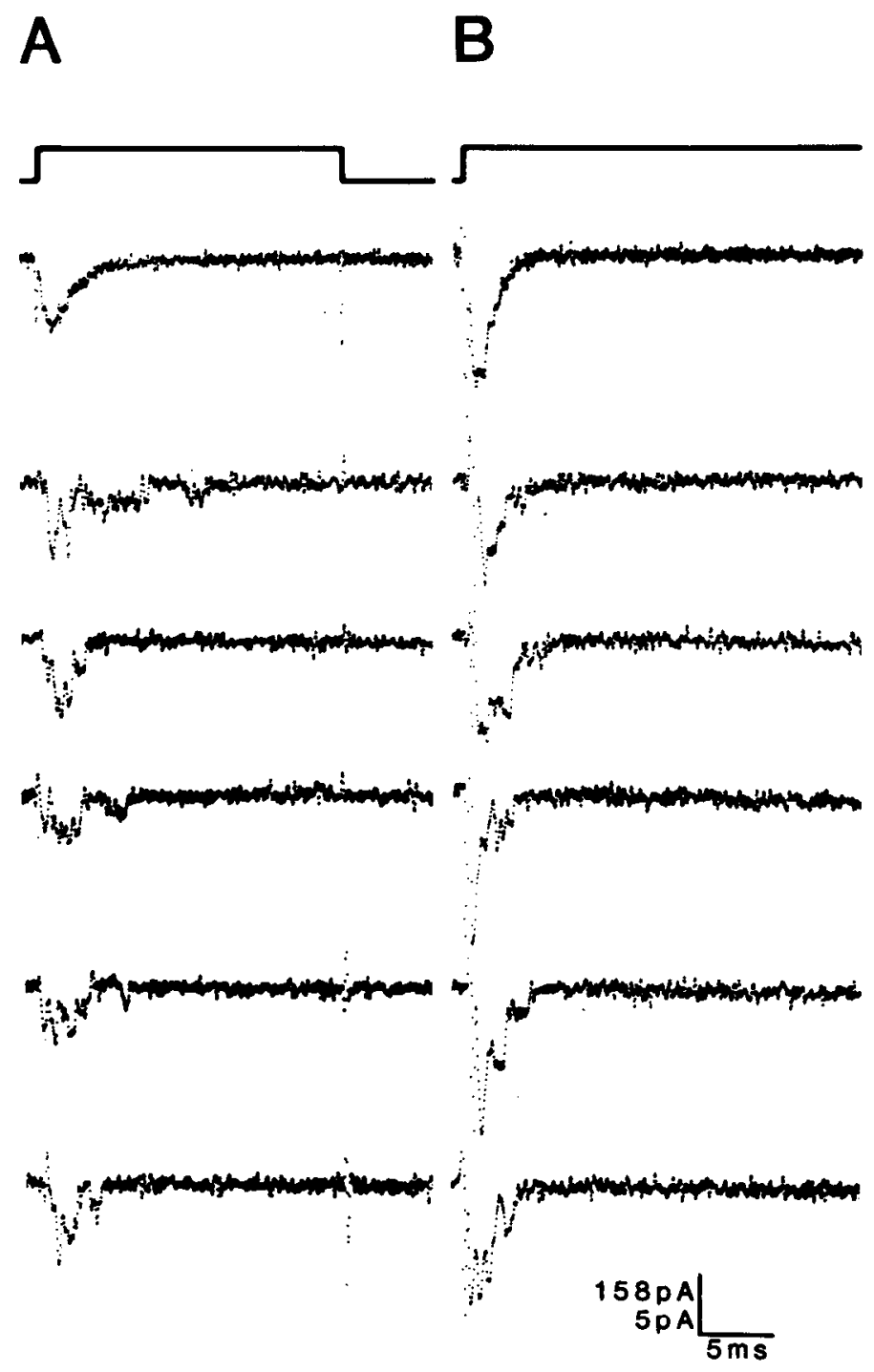

Figure 11. Examples of single channel records and summed currents from cells in muscle cultures $(A)$ and nerve-muscle culture $(B)$. The top trace is the $55 \mathrm{mV}$ voltage step. The second record is the summation of 50 individual records, examples of which are shown in the last five traces of each panel. The Bessel filter was set at $4 \mathrm{kHz}(-3 \mathrm{~dB}$ point) for the summed record and $3 \mathrm{kHz}$ for the last five records. Sample interval is $30 \mu \mathrm{sec}$. Top number on the vertical scale bar is for summed currents; the lower number is for individual records.

channel parameters. We, therefore, examined single-channel records to determine if the same mechanism applied for increasing $\mathrm{Na}$ current in the nerve muscle cocultures.

The two types of records obtained from cell-attached patches are shown in Figure 11 for a muscle culture (Fig. 11A) and a nervemuscle coculture (Fig. 11B). The top trace is the depolarizing voltage step. The last five records in each panel are examples of singlechannel current records in response to a $55-\mathrm{mV}$ depolarizing pulse. The second trace is the summed current record from 50 such responses after correction for leakage current. $l_{\rho k}$, the decay time constant and time-to-peak current, were compared between the two types of culture. Of 34 and 37 patches examined from muscle and nerve-muscle cultures, respectively, all showed channel activity. In five cases, when $3 \mu \mathrm{M}$ TTX was present in the electrode, no channel activity could be detected on cells in nerve-muscle cultures, as was the case for muscle cultured alone (see above).

To verify that the increase in $\dot{V}_{\max }$ reflects an increase in Na current density, $I_{p k}$ was measured. However, at both 40 and $50 \mathrm{mV}, I_{p k}$ was

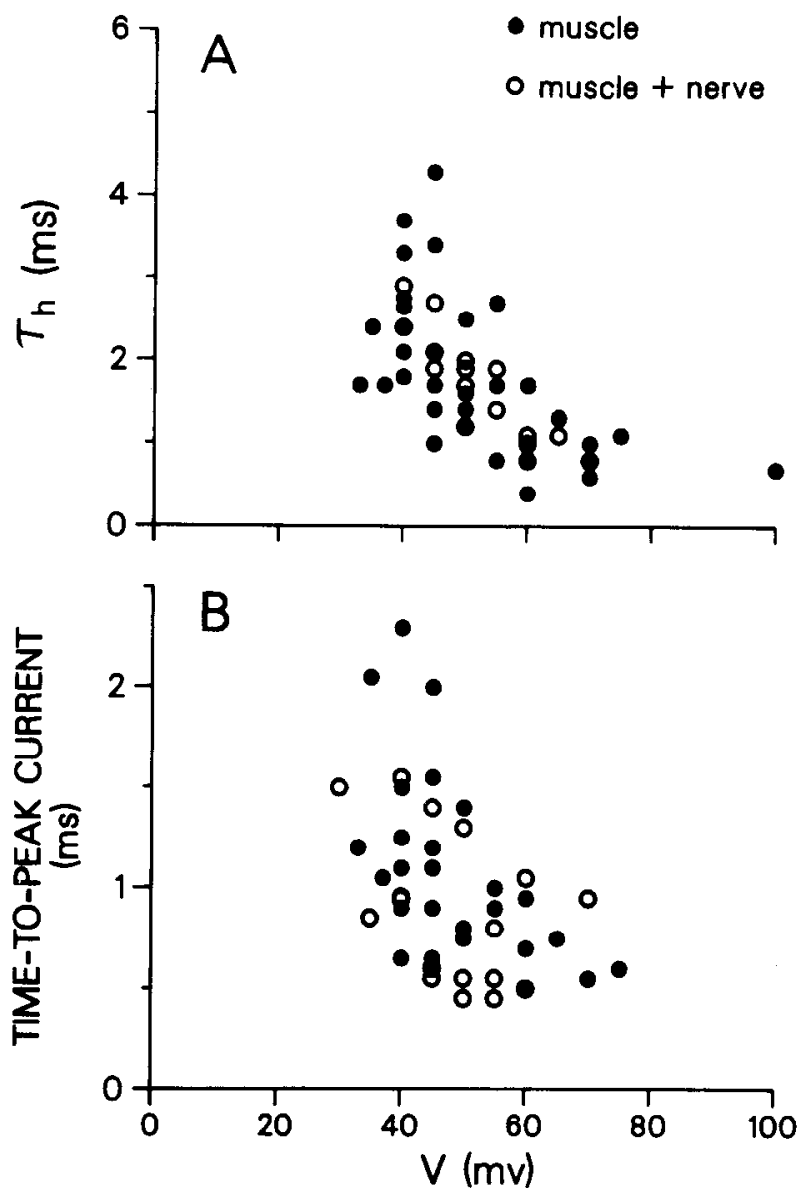

Figure 12. $\tau_{h}$ and time-to-peak current as a function of voltage. Values from muscle cultures $(\boldsymbol{O})$ and nerve-muscle $(O)$ overlap in some cases (slightly larger filled circles) $T=14 \pm 1^{\circ} \mathrm{C}$.

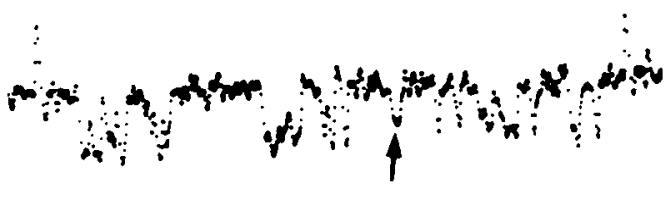$$
\text { ition }
$$

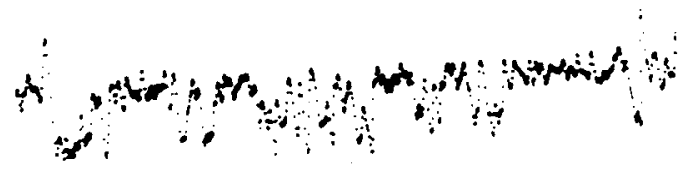

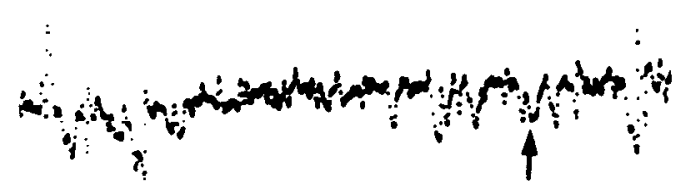

Figure 13. Example of single channel current records from a 4-day nervemuscle culture. Neural tube was added 3 days previous to recording. All records were in response to a $40-\mathrm{mV}$ depolarizing pulse. Arrows show examples of the smaller current amplitude channels. 
Figure 14. Amplitude (left panel) and open time histograms for muscle $(A)$ and nerve-muscle $(B)$ cultures in response to a $40-\mathrm{mV}$ step. Open time histograms (right panel) are plotted as $P(t)$ versus $t$ where $P(t)$ is the probability that the measured value is greater than $t$. The mean open time $\left(\tau_{0}\right)$ was calculated by the best visual fit of a single exponential. $\tau_{o}=0.14 \mathrm{msec}$ in $A_{;} \tau_{o}=$ $0.26 \mathrm{msec}$ for $B$. It should be noted that the mean current amplitude for the muscle cell in $A$ is smaller than normal.
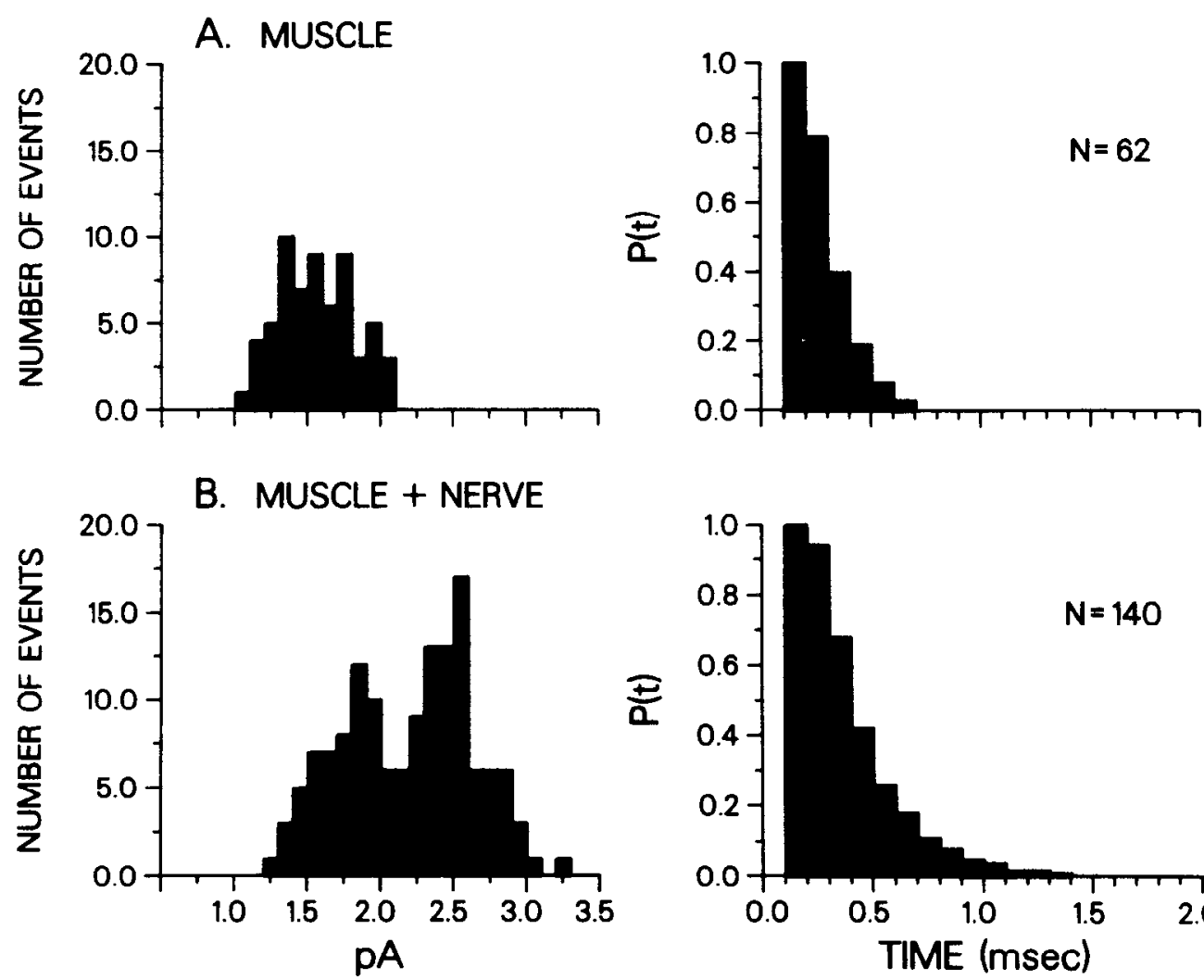

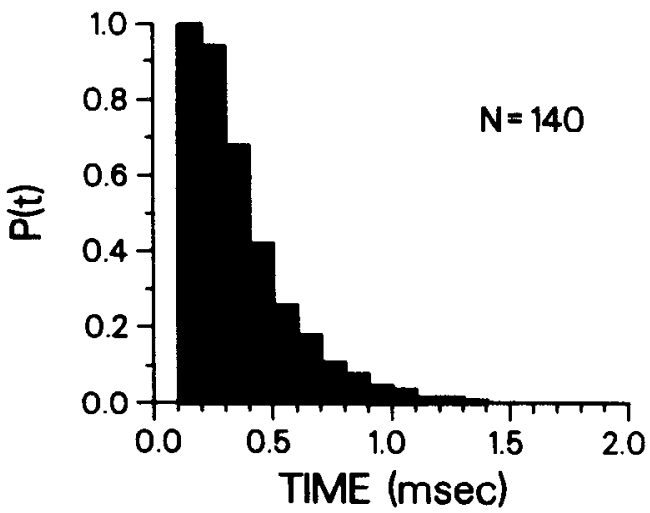

not significantly larger in nerve-muscle cultures compared to muscle cultures ( $\rho>0.1, n=6$ to 12) in spite of the apparent augmented range for cells in coculture: the range of $I_{p k}$ at $40 \mathrm{mV}$ was 0 to 211 $\mathrm{pA}$ for muscle cultures and 0 to $427 \mathrm{pA}$ for cocultures; at $50 \mathrm{mV}$, these respective ranges were 49 to $201 \mathrm{pA}$ and 38 to $1003 \mathrm{pA}$. The apparent discrepancy between $\dot{V}_{\max }$ and $I_{p k}$ measurements may be due to the small increase (two-fold) in $\dot{V}_{\max }$, which is not large enough to be detected with $I_{p k}$. We continued to characterize individual $\mathrm{Na}$ channels to ascertain the influence of neural tube addition on channel kinctics and conductance.

The time course of the summed current records was examined to determine whether activation and inactivation properties were affected by the addition of neural tube. In most cases, the time course of current decay was well fit to a single exponential. The values of $\tau_{h}$ at different potential steps for five muscle cultures and seven nerve-muscle cocultures are shown in Figure 12A. $\tau_{n}$ becomes smaller as the membrane patch is depolarized. In nervemuscle cocultures, $\tau_{h}$ is similar over a wide range of potentials compared to $\tau_{h}$ from muscle cultures. Time-to-peak current values are plotted against potential for both culture types in Figure 12B. Eight cells from muscle cultures and four cells from nerve-muscle cultures are included in this figure. As with $\tau_{h}$, time-to-peak current is not altered after the addition of neural tube cells to muscle cultures. These similarities suggest that the activation and inactivation processes underlying the time course of the summed currents are insensitive to neural tube addition.

Open times and unitary currents were measured from 12 cells in nerve-muscle cocultures. In three cases, only one class of $\mathrm{Na}$ channels was present. These channels were $2.4 \mathrm{pA}$ in amplitude at $40 \mathrm{mV}$ depolarized from resting potential and had a unitary conductance $(\gamma)$ of $28 \mathrm{pS}$. This is the same conductance value as seen in comparably aged muscle cultures (see above). In the majority of cases (9/12), the single-channel currents appeared to be composed of at least two conductance states (see Figure 13). However, amplitude histograms usually failed to reveal multiple discrete peaks, mainly due to the proximity of the two amplitude classes (the small class being about $70 \%$ of the large amplitude class) and the small number of events at any given potential. In one case, shown in Figure 14B, two peaks were discernible. The calculated unitary conductance from these cells ranged from 12 to $29 \mathrm{pS}$. However, the unitary current-voltage plots were not usually linear in these cases and thus, unitary conductance calculations are inaccurate. This problem is likely due to the presence of the smaller amplitude channels. Since individual amplitude classes could not be easily separated, the amplitude coefficient of variance was calculated as an altcrnative means of detcrmining the existence of two or more amplitude sizes. However, for cells in coculture $(n=12)$, as well as in muscle cultures $(n=11)$, the coefficient of variance was 0.17 over a 15 to $75 \mathrm{mV}$ depolarizing step range. This finding suggests that while there often appears to be a second conductance class of $\mathrm{Na}$ channels in nerve-muscle cultures, the smaller amplitude channels do not make a significant contribution to the total number of recorded single channel events. In fact, the range of amplitude values at $40 \mathrm{mV}$ is not statistically different between muscle and nerve-muscle cultures (1.4 to $2.6, n=12$, versus 1.6 to $2.7, n=7$, respectively).

While separation of channel types was not done, visual inspection of individual channel openings suggested that smaller amplitude events had similar open times as the larger events. Open time histograms could be well fit to a single exponential for both muscle cultures (Fig. 14A) and nerve-muscle cultures (Fig. 14B). The averaged open time at $40 \mathrm{mV}$ was $0.45 \pm 0.13 \mathrm{msec}(n=8)$ and 0.56 $\pm 0.13 \mathrm{msec}(n=8)$ for muscle cultures and nerve-muscle cocultures, respectively. At $50 \mathrm{mV}$, these values were $0.50 \mathrm{msec}( \pm 0.13$, $n=5)$ for muscle and $0.46 \mathrm{msec}( \pm 0.09, n=7)$ for cocultures. The averaged open times show no strong voltage dependence or differences between the two types of cultures.

\section{Discussion}

This paper examined the excitability of Xenopus myocytes, first developmentally over a 7-day period in culture, and then following the addition of neural tube. In muscle cells grown alone, the $\mathrm{Na}$ - 
dependent AP undergoes a 7.5 -fold increase in $\dot{V}_{\text {max }}$. While $\dot{V}_{\max }$ cannot be considered directly proportional to membrane current due to lack of isopotentiality during the AP, the observed increase in $\dot{V}_{\text {II:ax }}$ undoubtedly reflects a substantial increase in $\mathrm{Na}$ current density.

There is little evidence to suggest that the increased inward current is due to a shift in ionic dependence from $\mathrm{Ca}$ to $\mathrm{Na}$, although occasionally there is a prolonged depolarization after the stimulus is turned off which might indicate the presence of a Ca component. This contrasts with other muscle systems in vitro (Kano et al., 1972; Kidokoro, 1975; Spector and Prives, 1977), where there is an obvious early developmental dependency on $\mathrm{Ca}$. Perhaps a major Ca component disappears before the earliest time the cells are cultured (stage 18) or during the initial hours in culture prior to the first observations $(>20 \mathrm{hr}$ ). Delayed and anomalous rectification were present from the first day in culture.

Three mechanisms were examined which could account for the increased $\mathrm{Na}$ current using single-channel analysis: (1) greater unitary conductance in older cells; (2) alterations in activation and/ or inactivation parameters which might prolong $\mathrm{Na}$ flux; and (3) increased $\mathrm{Na}$ channel density. Unitary current and conductance (24 pS and 28 pS at 1 to 2 days and 4 to 6 days, respectively) did not increase significantly. The unitary conductance of 24 to $28 \mathrm{pS}$ is higher than reported in rat myoballs $(\gamma=18 \mathrm{pS}$; Sigworth and Neher; 1980), which is probably due to the ionic composition in the patch pipette. With relatively short open times $(0.4$ to $0.6 \mathrm{msec})$ at moderate potential steps (less than $50 \mathrm{mV}$ ) compared to $\tau_{n}(>1.0$ msec), the time course of decay reflects slow components of activation rather than inactivation (see Aldrich et al., 1983). So while we were unable to measure directly a time constant for activation because of the rapid onset of channel openings, the slower component, $\tau_{h}$, did not change, nor did the rapid phase as estimated from time-to-peak current. Likewise, inactivation, as measured by open timc, was not altered during the time in culturc. Thereforc, both conductance and kinetic measurements of individual $\mathrm{Na}$ channels show no change during development.

Without actually measuring $\mathrm{Na}$ channel density, the evidence suggests that the density of functional channels did increase over time. First, the percentage of membrane patches containing channels increased from 75 to $98 \%$. Second, the maximum $I_{p k}$ was smaller in younger cells, while unitary current remained constant.

In chick muscle, $\mathrm{Na}$ channel density was also shown to increase by using a variety of biochemical and electrophysiological techniques (Frelin et al., 1981; Baumgold et al., 1983a, b; Strichartz et al., 1983). Baumgold et al. (1983a, b) further suggested that there are two forms of $\mathrm{Na}$ channels: one which binds only scorpion toxin (ScTX) and is nonfunctional and a second, functional type which binds both ScTX and saxitoxin (STX). The density of both binding sites increased over time, with ScTx preceding STX by 1 to 2 days. They suggested that initially nonfunctioning channels which bind only ScTX. Later, the channels become functional and capable of binding both STX and ScTX. Presumably, the immature ScTX-binding (TTXinsensitive) channels all become functional and capable of binding STX (TTX-sensitive) simultaneously so that there is no population of TTX-insensitive, functional $\mathrm{Na}$ channels in cultured chick muscle (Kano et al., 1972) as is observed in denervated adult chicken muscle in vivo (Harris et al., 1973).

In vivo and in vitro rat muscle (Sherman and Catterall, 1982, 1983) also show increases in the densily of STX-binding sites. Cultured rat muscle, however, also has a population of TTX-resistant $\mathrm{Na}$ channels (Kidokoro, 1975: Sherman and Catterall, 1983) which are functional (Harris and Marshall, 1973; Kidokoro, 1975). In the present electrophysiological study, no effort was made to detect possible nonfunctional Na channels biochemically. However, more than $95 \%$ of the Na currents in 3-day and older cultured cells (TTX $\mathrm{K}_{0.5}=9 \mathrm{mM}$ ) were blocked with $0.1 \mu \mathrm{M}$ TTX, suggesting a negligible, if any, population of TTX-insensitive channels. This is not surprising, since $\mathrm{Na}$ channels on denervated adult frog muscle also are TTX sensitive (Nasledov and Thesleff, 1974).

In the second part of this study, we showed that neural tube addition to muscle cultures led to a further increase in the $\dot{V}_{\max }$ of TTX-sensitive Na APs in myocytes, suggestive of an increase in $\mathrm{Na}$ current density as observed developmentally. Our results from single-channel analyses can be summarized as follows: (1) Time-topeak current and the time constant for the current decay from summed records were similar in both muscle and nerve-muscle cocultures. In addition, there was no apparent alteration in the voltage sensitivity of these two parameters. (2) When only one class of channels was present, the single-channel current and unitary conductance (28 pS) was the same for both culture types. (3) The open time was similar in both cases. On the basis of these findings and the observed increase in $\dot{V}_{\max }$, we conclude that the addition of neural tube to muscle cultures results in an increase in Na channel density without alterations in the functional parameters of preexisting $\mathrm{Na}$ channels.

Interestingly, we found that in most cells $(9 / 12)$ at least one additional, smaller-amplitude Na channel was present (see Fig. 14B). In these cases, the conductance values generally were lower than $28 \mathrm{pS}$ due to contamination by the smaller conductance channels. The smaller amplitude channels likely contributed to the mean current amplitude more at certain voltages than others, making accurate conductance calculations difficult. However, since the different amplitude classes were inseparable, we were unable to determine conductance values for the two classes of $\mathrm{Na}$ channels. Instead, we assume that the larger-amplitude class corresponds to the 28 pS channel type; the new, smaller-amplitude channel type has an undetermined unitary conductance. Since the newly appearing channel type does not alter the amplitude coefficient of variance or the range in amplitude, the incrcased inward current accompanying neural tube addition likely reflects an increased density in the $28 \mathrm{pS}$ channel.

Kano et al. (1979) studied the effect of nerve on chick muscle in a different manner. $\dot{V}_{\max }$ measurements were made after nerve extract was added to cultured muscle. The nerve extract addition resulted in an increase in $\dot{V}_{\max }$. Since, in the present study, the augmented $\dot{V}_{\max }$ was seen in cells whether contacted with neurites or not, the increase in $\dot{V}_{\max }$ also may be mediated by a factor released by the neural tube cells. As was pointed out, however, we cannot be certain that the "noncontacted" muscle cells were not, at some point previous to recording, in contact with neurites, which was necessary for increasing $\dot{V}_{\text {max }}$. in fact, since neural tubes contain a variety of cell types, even if the enhanced $\dot{V}_{\max }$ depends on a factor, such a factor may originate from a non-nerve cell population.

Analysis of our summed current records revealed that the overall time course was unaffected by neural tube addition. As mentioned previously, since $\tau_{h}$ is likely a measure of the activation process (Aldrich et al., 1983), activation and inactivation (reflected by open time measurments) in Xenopus muscle are not altered upon neural tube addition. Pappone (1980) showed that denervation of rat muscle also had no effect on $\tau_{h}$ and $\tau_{m}$ (activation time constant).

One of the most interesting results from this study is that $\mathrm{Na}$ channels and AChR channels appear to be regulated differently. In the same Xenopus muscle preparation, AChRs exhibit a reduction in mean open time as measured by spectral analysis of voltage fluctuations (Brehm et al., 1982) without any alteration in channel density during development (Kidokoro and Gruener, 1982; Brehm et al., 1983a). These and subsequent single channel experiments (Brehm et al., 1983b) showed that the decrease in open time was due to a shift in the relative amounts of two types of AChR channels: one with a mean open time of $0.7 \mathrm{msec}$ and conductance of $60 \mathrm{pS}$; the other with a 3-msec open time and a conductance of $42 \mathrm{pS}$. For $\mathrm{Na}$ channels, the increase in $\mathrm{Na}$ current can be accounted for by an increase in channel density without concommitant functional changes. In the case of AChRs, the cell has effectively increased current through the receptor channel without altering channel den- 
sity. This may occur by modification of a single pool of AChRs which ultimately generates different functional AChRs. Alternatively, one might view this as a somewhat similar regulatory mechanism as for the $\mathrm{Na}$ channel if the two receptor types originate as two different gene products and only their relative amounts are modified (i.e. changing the density of each).

In the case of muscle cells grown in the presence of neural tube, the smaller-amplitude, longer-open time AChR channels increase in density. For Na channels, neural tube additions appears to induce a second channel type. In addition, the density of the original channel type may increase. Regulation of the $\mathrm{Na}$ channel and AChR may occur similarly via modification in the relative expression of two different gene products. In the case of the $\mathrm{Na}$ channel, the smaller conducting channel may be expressed in very low levels in muscle cultures alone and go undetected. Alternatively, perhaps the effect of nerve addition is to induce a new type of $\mathrm{Na}$ channel. In both cases, developmentally and under neural control, it will be interesting to establish whether the cell regulates $\mathrm{Na}$ and $\mathrm{AChR}$ channels by similar mechanisms.

\section{References}

Aldrich, R. W., D. P. Corey and C. F. Stevens (1983) A reinterpretation of mammalian sodium channel gating based on single channel recording Nature 306: 436-441.

Baccaglini, P. I., and N. C. Spitzer (1977) Developmental changes in the inward current of the action potential of Rohon-Beard neurones. J. Physiol. (Lond.) 271: 93-117.

Baumgold, J., J. B. Parent, and I. Spector (1983a) Development of sodium channels during differentiation of chick skeletal muscle in culture. I. Binding studies. J. Neurosci. 3: 995-1003.

Baumgold, J., J. B. Parent, and I. Spector (1983b) Development of sodium channels during differentiation of chick skeletal muscle in culture. $11 .{ }^{22} \mathrm{Na}^{+}$ uptake and electrophysiological studies. J. Neurosci. 3: 1004-1013.

Blackshaw, S., and A. Warner (1976) Onset of acetylcholine sensitivity and endplate activity in developing myotome muscles of Xenopus. Nature 262. 217-218.

Brehm, P., J. H. Steinbach, and Y. Kidokoro (1982) Channel opentime of acetylcholine receptors on Xenopus muscle cells in dissociated cell culture. Dev. Biol. 91: 93-102.

Brehm, P., F. Moody-Corbett, and Y. Kidokoro (1983a) Developmental alterations in acetylcholine receptor channel properties proceed in the absence of innervation. Neuroscience, Abstr, 9: 1180.

Brehm, P., E. Yeh, J. Patrick, and Y. Kidokoro (1983b) Metabolism of acetylcholine receptors on embryonic amphibian muscle. J. Neurosci. 3 : 101-107.

Chow, I., and M. W. Cohen (1983) Developmental changes in the distribution of acetylcholine receptors in the myotomes of Xenopus laevis. J. Physiol. (Lond.) 339: 553-571.

Frankenhaeuser, B., and L. E. Moore (1963) The effect of temperature on the sodium and potassium permeability changes in myelinated nerve fibers of Xenopus laevis. J. Physiol. (Lond.) 169: 431-437.

Frelin, C., A. Lombet, P. Vigne, G. Romey, and M. Lazdunski (1981) The appearance of voltage-sensitive $\mathrm{Na}^{+}$channels during the in vitro differentiation of embryonic chick skeletal muscle cells. J. Biol. Chem. 256: 1235512361

Hamill, O. P., A. Marty, E. Neher, B. Sakmann, and F. J. Sigworth (1981) Improved patch-clamp techniques for high-resolution current recording from cells and cell-free membrane patches. Pflügers Arch. 391: 85-100.

Harris, J. B., and M. W. Marshall (1973) Tetrodotoxin-resistant action potentials in newborn rat muscle. Nature New Biol. 243: 191-192.

Harris, J. B., and S. Thesleff (1971) Studies on tetrodotoxin resistant action potentials in denervated skeletal muscle. Acta Physiol. Scand. 83: 382388.
Harris, J. B., M. W. Marshall, and M. R. Ward (1973) Action potential generation in singly and multiply innervated avian muscle fibres. J. Physiol. (Lond.) 232: 51P-52P.

Kano, M. (1975) Development of excitability in embryonic chick skeletal muscle cell. J. Cell. Physiol. 86: 503-510

Kano, M., Y. Shimada, and K. Ishikawa (1972) Electrogenesis of embryonic chick skeletal muscle cells differentiated in vitro. J. Cell. Physiol. 79: 363366.

Kano, M., N. Suzuki, and H. Ojima (1979) Neurotrophic effect of nerve extract on development of tetrodotoxin-sensitive spike potential in skeletal muscle cells in culture. J. Physiol. (Lond.) 99: 327-332.

Kidokoro, Y. (1975) Sodium and calcium components of the action potential in a developing skeletal muscle cell line. J. Physiol. (Lond.) 244: 145159.

Kidokoro, Y., and R. Gruener (1982) Distribution and density of alphabungarotoxin binding sites an innervated and noninnervated Xenopus muscle cells in culture. Dev. Biol. 91: 78-95.

Kidokoro, Y., M. J. Anderson, and R. Gruener (1980) Changes in synaptic potential properties during acetylcholine receptor accumulation and neurospecific interactions in Xenopus nerve-muscle cell culture. Dev. Biol. 78. 464-483

Kidokoro, Y., P. Brehm, and R. Gruener (1982) Developmental changes in acetylcholine receptor distribution and channel properties in Xenopus nerve-muscle cultures. In Muscle Development: Molecular and Cellular Control, Cold Spring Harbor Laboratory, Cold Spring Harbor, NY.

Kullberg, R. W., T. L. Lentz, and M. W. Cohen (1977) Development of the myotomal neuromuscular junction in Xenopus laevis: An electrophysiological and fine-structural study. Dev. Biol. 60: 101-129.

Nasledov, G. A., and S. Thesleff (1974) Denervation changes in frog skeletal muscle. Acta Physiol. Scand. 90: 370-380.

Neher, E. and J. H. Steinbach (1978) Local anesthetics transiently block currents through single AChR channels. J. Physiol. (Lond.) 277: 153-176.

Nieuwkoop, P. D., and J. Faber (1967) Normal table of Xenopus laevis (Daudin), Elsevier-North Holland Publishing Co., Amsterdam.

Ohmori, H., and M. Yoshii (1977) Surface potential reflected in both gating and permeation mechanisms of sodium and calcium channels of the tunicate egg cell membrane. J. Physiol. (Lond.) 267: 429-463.

Okamoto, H., K. Takahashi, and M. Yoshii (1976) Membrane currents of the tunicate egg under the voltage-clamp condition. J. Physiol. (Lond.) 254: $607-638$.

Pappone, P. (1980) Voltage-clamp experiments in normal and denervated mammalian skeletal muscle fibres. J. Physiol. (Lond.) 306: 377-110.

Redfern, P. and S. Thesleff (1971) Action potential generation in denervated rat skeletal muscle. II. The action of tetrodotoxin. Acta Physiol. Scand. 82. 70-78.

Sherman, S. J., and W. A. Catterall 1982. Biphasic regulation of development of the high-affinity saxitoxin receptor by innervation in rat skeletal muscle. J. Gen. Physiol. 80: 753-768.

Sherman, S. J., and W. A. Catterall (1983) Regulation of sodium channel subtrates during development of mammalian muscle cells. J. Gen. Physiol. 82: $8 \mathrm{~A}$.

Siegel, S. (1956) Nonparametric Statistics, McGraw-Hill, New York.

Sigworth, F. J., and E. Neher (1980) Single $\mathrm{Na}^{+}$channel currents observed in cultured rat muscle cells. Nature 287: 443-449.

Spector, I., and J. M. Prives (1977) Development of electrophysiological and biochemical membrane properties during differcntiation of embryonic skeletal muscle in culture. Proc. Natl. Acad. Sci. U. S. A. 74: 5166-5170.

Strichartz, G., D. Bar-Sagi, and J. Prives (1983) Differential expression of sodium chanmel activities during the development of chick muscle cells in culture. J. Gen. Physiol. 82: 356-384.

Willard, A. (1980) Electrical excitability of outgrowing neurites of embryonic neurones in cultures of dissociated neural plate of Xenopus laevis. J. Physiol. (Lond.) 301: 115-128.

Yamamoto, D., J. Z. Yeh, and T. Narahashi (1983) Current-voltage relationships of single sodium channels in neuroblastoma cells. Biophys. J. 41: $51 \mathrm{a}$. 